International Journal of Instruction e-ISSN: 1308-1470 • www.e-iji.net

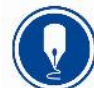

October $2021 \bullet$ Vol.14, No.4

p-ISSN: 1694-609X

pp. 321-336

Article submission code:

20200720030315

Received: 20/07/2020

Revision: 13/03/2021
Accepted: 05/04/2021

OnlineFirst: 17/07/2021

\title{
Creative Problem-Solving Learning through Open-Ended Experiment for Students' Understanding and Scientific Work Using Online Learning
}

Leny Heliawati

Correspondence author, Pakuan University, Indonesia, leny_heliawati@unpak.ac.id

Idham Ibnu Afakillah

Pakuan University, Indonesia, idhamibnul@gmail.com

Indarini Dwi Pursitasari

Pakuan University, Indonesia, indarini.dp@ unpak.ac.id

The purpose of this research is to improve students' understanding and the ability to perform scientific work through creative problem-solving learning with the open-ended experiment approach to the separation of mixtures material using online learning. The study used a quasi-experimental method with the nonequivalent pretest-posttest control group research design. This study involved 72 students divided into two classes, 36 students in the control class and 36 students in the experimental class. Indicators of scientific work are formulating problems, describing problems, designing investigations, conducting experiments, processing data, and concluding. The results of the study showed an increase in the students' ability to perform scientific work, obtaining N-Gain of $71 \%$ (experimental class) and $48 \%$ (control class), as well as the value of $t_{\text {count }}=8.807$ indicating $t_{\text {count }}>t_{\text {table. }}$. The percentage of students' scientific work in the experimental class was in a very good category with $72 \%$, while the control class was $53 \%$. Thus, creative problem-solving learning through the open-ended experiment can improve students' understanding and scientific work.

Keywords: creative problem-solving learning, open-ended experiment, students' scientific work, online learning

\section{INTRODUCTION}

Students' difficulty in understanding and developing concepts and theories in daily life in the form of scientific work is one of the issues in chemistry learning. From the interviews with the students, it is known that current scientific work activities are teacher-centered, and the learning is still conventional. Thus, when scientific work is done, students are only fixated with its instructions. They only followed the steps in the instructions and applied instructions from the teacher. Students become passive and lessstimulated in carrying out development through scientific work. As a result, students

Citation: Heliawati, L., Afakillah, I. I., \& Pursitasari, I. D. (2021). Creative Problem-Solving Learning through Open-Ended Experiment for Students' Understanding and Scientific Work Using Online Learning. International Journal of Instruction, 14(4), 321-336. https://doi.org/10.29333/iji.2021.14419a 
might not develop chemical concepts in daily life through scientific work. This fact is reinforced by the survey data based on the value of the scientific work of students where $29 \%$ achieved a good category, 34\% achieved medium category, and 37\% achieved poor category. It can be concluded that there is the potential for real problems in the learning process that must be solved.

The learning process should not always be focused on the teacher, so that students can develop their potential for knowledge of chemistry in daily life through scientific work. Research conducted by Rebecca and Nsimeneabasi (2017) and Nurdeli et al. (2017) argued that learning that only follows the teacher causes students to become passive, so students cannot develop reasoning power to solve problems, this, of course, affects process skills.

Therefore, learning activities must engage students and allow them to connect learning to their daily lives. Developing chemical concepts in everyday life can stimulate thinking and push students to solve difficulties. Novikasari (2009) argued that learning activities necessitate students' ability to handle problems in various ways in order to develop intellectual potential and experience in the process of discovering something new.

Aka et al., (2010); Kazembe and Methias (2010); and Kubiatko (2017) revealed that learning with scientific work methods makes passive students active. Moreover, students can develop their potential to solve problems with a variety of solutions and possible correct answers through work, action, and thinking activities. Students might be more flexible in looking for the right solution and actualize it through communicating the results of the experiment from the initial step of observation to concluding, as well as produce more meaningful knowledge.

Learning chemistry as a science is strongly linked to the development of knowledge and skills through scientific work activities that may raise students' enthusiasm in learning, expand their knowledge, and improve their understanding, to make the learning process easier for them (Ottander and Grelsson 2006; Farsakoglu et al., 2008; Akinbobola and Afolabi. 2010). Scientific work can be done through independent activities or small groups; it is generally done in laboratories but can also be done in an open space or garden. (Rosmalinda, et al., 2013; Amna 2017).

Previous studies conducted by Risna et al., (2017); Cahaya et al., (2019); Adel and Yousra (2020) regarding creative problem-solving learning based on scientific work proved that it could increase student activity. Students can understand concepts to achieve maximum learning outcomes and can develop thinking skills to solve problems. Further studies by Chansyanah et al., (2018); Laura et al., (2019); and Reynders et al., (2019) concluded that scientific work could increase students' activeness, understanding, and the ability to perform real scientific work, also encourage students' environmental awareness as well as solve problems creatively.

Tina et al., (2013) suggested that an open-ended learning approach can help students to solve problems. An open-ended approach is a learning that presents a problem that has more than one correct method or solution for students who face a problem with a variety 
of correct answers (Munroe, 2015; Bartholomew and Strimel, 2018). The open-ended approach provides opportunities for students to analyze various strategies that are believed to be in the ability to describe problems to foster originality of ideas (Martunis, 2014).

The subject matter discussed in this study is the separation of mixtures. The material, including concepts and skills, is closely related to daily life. The importance of doing scientific work on separation of mixture subject matter is to increase students' enthusiasm since they are actively involved in constructing knowledge that impacts their independence. Moreover, scientific work is essential in learning separation of mixture for it can form scientific attitudes, for it can link learning with daily life in the real world, provide opportunities to research which can encourage students to think scientifically and rationally.

The internet is one of the media capable of providing information, which is not limited by time and space to face technological advances. Effective use of technology is used in the learning process (Tatyana et al., 2020). The internet has a vast network of various fields, including education as a learning resource for students. Therefore, the addition of learning resources is expected to increase student knowledge to be more comprehensive and improve psychomotor through scientific work activities (Siti and Sufen, 2019). By the studies of Diane et al., (2013) and Baker et al., (2016), using the internet as a learning resource where students practice scientific skills. Thus, students can get the maximum benefit both from the process and the results of learning.

It is required to produce learning that is capable of growing understanding and developing students' scientific work skills in solving difficulties, which is creative problem-solving learning through open-ended experimentation, as the result of the problems outlined. The learning process centered on students accompanied by strengthening skills in the inquiry process (Vidal, 2010; Ridong et al., 2017) can be a guideline for developing creative thinking skills and helping students to be more motivated in learning activities. Thus, the students are not only memorizing but also understanding the concepts acquired that later benefit them. Moreover, learning using scientific work can also increase scientific creativity in solving problems (Margaret et al., 2015; Jalimah et al., 2019). Creative problem-solving learning is seen as being able to solve problems creatively (Seechalio et al., 2011; Hobri et al., 2020), especially when it is combined with the open-ended approach which has a significant effect on problems solving with creative thinking skills (Noer, 2008). 2011; Lambertus et al., 2013).

Creative problem-solving learning combined with the open-ended approach that can provide flexibility for students to explore problems in depth with creative solutions (Lim et al., 2016), especially those related to scientific work which can be implemented in daily life. Indicators of the ability to perform scientific work are formulating problems, describing problems, designing investigations, conducting experiments, processing data, and concluding (National Research Council, 2000). Thus, this study aims to improve the understanding and scientific skills of Vocational High School students through creative problem-solving learning on the separation of mixture subject matter with open-ended experimentation through online learning. However, the extent of the learning process 
influence has on students, understanding, and level of scientific work cannot yet be revealed. Therefore, the researcher considers it necessary to conduct creative problemsolving learning research with open-ended experiments.

\section{METHOD}

\section{Research Design}

This study used a quasi-experimental method referring to Fraenkel and Norman (2007). The design used in this study was a nonequivalent pretest-posttest control group design. The design is described as follows :

Table 1

Research design

\begin{tabular}{|c|c|c|c|}
\hline Class & Pretest & Treatment & Post-test \\
\hline Experiment & $\mathrm{O}_{1}$ & $\mathrm{X}$ & $\mathrm{O}_{2}$ \\
\hline Control & $\mathrm{O}_{3}$ & - & $\mathrm{O}_{4}$ \\
\hline
\end{tabular}

Fraenkel and Norman (2007)

Table 1 showed that the experimental group applied creative problem-solving learning with open-ended experiment and the control group applied conventional learning. $\mathrm{O}_{1}$ and $\mathrm{O}_{3}$ are two groups that are considered to have the same metacognitive ability and were tested with a pretest. $\mathrm{O}_{2}$ is the result of the experimental group, while $\mathrm{O}_{4}$ is the result of the control group.

This study involved two research groups which were given different treatment. The first group is the experimental group which is given creative problem-solving learning treatment with open-ended experiment, and the second group is the control group which is given a conventional learning treatment model using lecture and assignment methods. The independent variable in this study is creative problem-solving learning through open experiments, while the dependent variable is the understanding and ability students' ability to perform scientific work.

\section{Participants}

This research was carried out in the 2019/2020 academic year on mixed separation material. The participants in this study were 10th graders of Industrial Mechanical Engineering at SMKN 1 Waringinkurung, Serang Regency, Banten, Indonesia who collected 72 students consisting of 2 classes. The sampling technique used is probability sampling. Simple random sampling technique was used to determine the experimental class and the control class. This is done because the population is considered homogeneous by first doing the homogeneity test. So that Class 10 Industrial Mechanical Engineering 1 with 36 students in the experimental class, and Class 10 Industrial Mechanical Engineering 2 with 36 students in the control class.

\section{Instrument}

Data were collected using two research instruments. The first instrument is essay questions under the learning indicators to determine students' understanding. Before the 
use, validation was done by experts who are two competent lecturers and two chemistry teachers who have five years of the learning experience. After that, the instrument was used for the pretest and posttest for the experimental class and the control class. Meanwhile, the second instrument is worksheets based on scientific work indicators used to measure students' ability to perform scientific work. Indicators of scientific work are formulating problems, describing problems, designing investigations, conducting experiments, processing data, and concluding (National Research Council, 2000). Creative problem-solving learning with open-ended experiments is hoped to increase students' understanding and scientific work.

\section{Data Analysis}

The method of data collection the method of measuring student understanding through pretest-posttest questions. Pretest questions are to determine the initial level of student understanding, and posttest to see an increase in student understanding. The form of questions used in the experimental class and the control class is the same. The obtained data on the students' understanding was processed using the gain test $\langle\mathrm{g}\rangle$, which then interpreted using the gain index criteria presented in Table 2.

Table 2

$\mathrm{N}$-gain index criteria

\begin{tabular}{ll}
\hline Percentage of answer & Criteria \\
\hline $\mathrm{g}>70$ & High \\
\hline $30<\mathrm{g}<70$ & Medium \\
\hline $\mathrm{g}<30$ & Low \\
\hline
\end{tabular}

Hake (1998)

A hypothesis test was performed to strengthen the data analysis of student understanding results using the t-test (independent t-test). The criteria used were if the value of $t_{\text {count }}>$

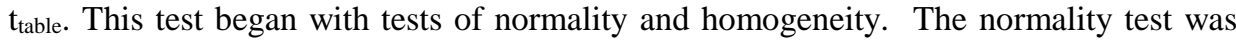
done using Shapiro-Wilk with sig. $>\alpha(\alpha=0.05)$ considered as normal data. Meanwhile, the homogeneity test was performed using the Levene Test (Test of Homogeneity of Variances $)$ with Sig. $>\alpha(\alpha=0.05)$ the variance data of the experimental and control group considered as homogeneous.

Scientific worksheets were used to obtain data on students' ability in conducting scientific work. During the learning process, was carried out assessment of aspects of a scientific worksheets. Scoring criteria refer to predetermined aspect scores. The assessment results were then averaged by the formula below:

Score $=\frac{\text { Eobtained score }}{\text { Maximum score }} \times 100$

Sudjana (2002)

The obtained score of the scientific work was then interpreted to find out the criteria for scientific work activities which can be seen in Table 3. 
Table 3

Interpretations of students' ability to perform scientific work

\begin{tabular}{ll}
\hline Interval $(\%)$ & Category \\
\hline $81-100$ & Very Good \\
\hline $61-80$ & Good \\
\hline $41-60$ & Medium \\
\hline $21-40$ & Low \\
\hline $0-20$ & Very Low \\
\hline
\end{tabular}

Kubiszyn and Gary (2015)

\section{FINDINGS AND DISCUSSION}

Based on the results of the study, the obtained data indicate the success in increasing student understanding in the learning process and students' ability to perform scientific work. The success of students in the learning process is shown in Table 4.

Table 4

$\mathrm{N}$-Gain test results of students' understanding of the experimental class and the control class

\begin{tabular}{lll}
\hline Average & Experimental class & Control class \\
\hline Pretest & 64 & 63 \\
\hline Posttest & 90 & 81 \\
\hline N-Gain (\%) & 71 (high) & 48 (medium) \\
\hline
\end{tabular}

$\mathrm{N}$-Gain test based on indicators of the ability to perform scientific work was also conducted to investigate student understanding. The results are shown in Table 5.

Table 5

$\mathrm{N}$-Gain test results of students' understanding based on scientific work indicators

\begin{tabular}{lll}
\hline \multirow{2}{*}{ Indicators of Scientific Skills } & N-Gain $(\%)$ & \\
\cline { 2 - 3 } & Experimental & Control \\
\hline Formulating the problem & 67 & 44 \\
\hline Describing the problem & 64 & 39 \\
\hline Designing investigation & 71 & 47 \\
\hline Conducting experiments & 80 & 58 \\
\hline Processing the data & 74 & 52 \\
\hline Concluding & 76 & 46 \\
\hline
\end{tabular}

The results of the N-Gain analysis based on Table 5 show that students' understanding in the experimental class is better than in the control class. Furthermore, normality and homogeneity tests were carried out and are shown in Table 6. 
Table 6

Recapitulation of the normality and homogeneity tests of the experimental and control classes

\begin{tabular}{llll}
\hline $\begin{array}{l}\text { Data Component } \\
\text { (Sig. value) }\end{array}$ & Experimental class & $\begin{array}{l}\text { Control } \\
\text { class }\end{array}$ & Description \\
\hline Normality test & 0.111 & 0.088 & Normal distribution \\
\hline Homogeneity test & 0.064 & & Homogeneous variance \\
\hline
\end{tabular}

Table 6 presents the data analysis results of students' understanding which were normally distributed and homogeneous. Thus, hypothesis testing can be done using the independent t-test using SPSS program in which the results are presented in Table 7.

Table 7

Results of t-test (independent t-test).

\begin{tabular}{llll}
\hline $\mathrm{df}=72$ & $\mathrm{t}_{\text {count }}$ & $\mathrm{t}_{\text {table }}$ & Description \\
\hline$(\alpha=0.05)$ & 8.807 & 1.927 & $\mathrm{t}_{\text {count }}>\mathrm{t}_{\text {table }}$ \\
\hline
\end{tabular}

Table 7 shows that $t_{\text {count }}>t_{\text {table }}$ indicating there are significant differences between the understanding of students who used creative problem-solving learning through openended experiments and those who did not.

Based on the data analysis of students' understanding of the control and experimental class, it was found that there was a success in increasing students' understanding in the experimental class compared to the control class. N-Gain scores for students in quantity showed the differences from each indicator of scientific work. In general, the N-Gain scores in the experimental group are relatively good for the obtained N-Gain scores reaching the moderate as well as high categories. In the indicator formulating the problem and describing the problem, the score of N-Gain obtained in each class was in the moderate category. In formulating the problem, the experimental class obtained $67 \%$, and the control class obtained $44 \%$. Meanwhile, the N-Gain scores of the indicator of describing the problem, the experimental class obtained $64 \%$, and the control class obtained $39 \%$.

Some students in the experimental class or the control class were not correct in formulating the problem. Students did not formulate in question sentences and question the relationship between things that influence. They also did not be able to describe the problem in detail under the concept and theory. The answers from the students were not fully detailed. They did not understand how to apply the appropriate concept. Rahman et al., (2014) stated that students still need adequate and guided interactions to understand better a problem and maintain the quality of their understanding.

The obtained high results on the N-Gain scores of students' understanding of each aspect of scientific work indicators in the experimental class prove that creative problemsolving learning through the open-ended experiment with online learning can motivate students to be active in the learning process. Accordingly, students' understanding of chemical concepts is not easily forgotten for ongoing learning makes the learning process more meaningful. This is in line with a study conducted by Fian et al., (2012); 
Ahmad and Parlindungan (2015) stated that experimental-based creative problemsolving learning can increase learning activities higher than conventional learning, and can improve cognitive abilities and creativity in solving problems. Siti and Soeprojo (2015); Yunnel and Yarman (2019) further explained that creative problem-solving learning could improve students' understanding and foster students' creative thinking skills because students are actively involved and will have a positive impact on learning outcomes.

The open-ended approach to students was trained to provide a variety of problemsolving. Raden and Idris (2014) argued that the open-ended approach is effective in the aspect of problem-solving ability since students are required to develop individual thinking. Students might also be able to learn without space and time restrictions, to learn anywhere and anytime, and to develop concepts and materials in daily life creatively. Studies conducted by Noorsalim et al., (2014) and Arif et al., (2018) revealed that the application of online media could encourage students to learn more actively and make it easier for students to understand chemistry subject material to get the best results.

Data on the measurement results of students' ability in conducting scientific work can be seen from the percentage acquisition of scientific skills level. Data analysis of students' scientific skills is shown in Table 8.

Table 8

Analysis results of students scientific work

\begin{tabular}{lcllll}
\hline Category & Percentage & Control & \multicolumn{3}{l}{ Experimental } \\
\cline { 2 - 6 } & $(\%)$ & Frequency & Percentage (\%) & Frequency & Percentage (\%) \\
\hline Very Good & $81-100$ & 19 & 53 & 26 & 72 \\
\hline Good & $61-80$ & 17 & 47 & 10 & 28 \\
\hline Fair & $41-60$ & 0 & 0 & 0 & 0 \\
\hline Low & $21-40$ & 0 & 0 & 0 & 0 \\
\hline Very Low & $0-20$ & 0 & 0 & 0 & 0 \\
\hline
\end{tabular}

Based on the data analysis described above, it can be seen that there are differences in the ability of students in the experimental class and the control class in doing scientific work. This difference showed that the experimental class is better than the control class. Improving students' scientific skills in the experimental class is characterized by students being able to carry out scientific work activities creatively, independently, and only in various ways and using tools and materials available in the surroundings. Alfi $e t$ al., (2019) revealed that students can find many ideas to solve problems through scientific work. Furthermore, Widyatmoko and Pamelasari (2012); Chansyanah et al., (2018); and Nancy et al., (2019) also revealed that by giving assignments to students to do scientific work independently, they could develop their knowledge to do scientific work only by using tools and materials around them. Thus, students could think creatively and be able to increase their motivation to understand chemistry as well as develop scientific skills in daily life. 
Scientific work-based learning stimulates students to be active in scientific activities. Students in the experimental class proved this at the stage of problem formulation. They were able to plan simple scientific work which included making plans and formulating the benefits and objectives of scientific work to be carried out. Royston and Roni (2017) argued that students who have a creative mindset are associated with creative performance. Moreover, they could also write provisional estimates on scientific work. In the stage of describing the problem, students were able to develop and elaborate their ideas on the context of the problem based on theory. They were able to find and to write theory concepts which indirectly increase students' knowledge to solve problems. This is following in accordance with research conducted by Wardani (2008) stated that concluded that scientific work activities emphasize students to gain knowledge in solving problems.

At the stage of designing an inquiry, students were able to generate many ideas for doing simple scientific work. They had also been able to write tools and materials and to write steps of scientific work in a structured manner. Tools used by students in scientific work were simple tools from the surrounding area as a part of the open-ended experiment. Bethany and Heather (2016) said that the open-ended experiment provides a real learning environment for students which increases their confidence in scientific work. Furthermore, Margaret et al., (2015); Hilarius et al., (2019); and Zainuddin et al., (2020) stated that student-centered learning based on science process skills can develop scientific concepts of knowledge and creativity to design experiments creatively in solving problems.

At the stage of carrying out scientific work, students performed structurally under the written work steps and carefully observing changes in scientific work done evidenced by the acquisition of complete scientific work data. This is as stated by Ryan et al., (2016) and Soka et al., (2019) that through observations in experiments, students have linked scientific work procedures to show that they can solve problems. In the data processing stage, students were able to identify the data needed and make correct interpretations of the data that has been obtained. They are also able to write and explain data in tabulated form clearly.

At the conclusion stage, students were able to accurately determine the findings of simple scientific work and associate conclusions with the correct data at the conclusion stage. Furthermore, they were able to improve scientific work by communicating the outcomes through scientific work reports created independently using available resources such as books, articles, and other sources from the Internet. Therefore, mastering creative problem solving through an open-ended experiment can help students become more engaged in their studies. They can discover and develop concept knowledge during the learning process through relevant tasks. This is the following research conducted by Wulandari and Mashuri (2014) and Ayel et al., (2017) which revealed the application of the open-ended experiment approach in learning could improve students' thinking creatively to solve problems. Furthermore, Wawan et al. (2019) and Satish and Vinayak (2019) claimed that open-ended experiments can teach students to think independently and work harder to generate scientific works, where 
students are given the freedom to construct their experiments in order to expand their understanding.

Studies by Gail et al., (2007); Turner and Parisi (2008); Safarudin et al., (2020) successfully revealed that learning through online scientific work is positively correlated with students' scientific work. Moreover, students' achievement of competence with scientific work activities at home is better than scientific work on campus. Furthermore, with the help of electronic media in learning can increase student motivation and process skills. Laite and Luis (2013) stated one of the factors that can foster student motivation to learn science with the existence of scientific work activities. Furthermore, Planinsic (2007); Devin and Kimberley (2011) stated that scientific work carried out independently by students can improve understanding of concepts and belief in selfability characterized by effort and independence. Other researches conducted by Kate $e t$ al., (2014), Ruomei (2015); Diana et al., (2018); and Nicolas et al., (2019) concluded that scientific work learning based on students would have a positive impact for it can make students feel a significant learning benefit, increase effective conceptual understanding, and provide increased student learning opportunities towards problemsolving through scientific work.

\section{CONCLUSION}

The conclusion from the research results that the application of creative problem solving learning with open-ended experiments can improve student understanding. This is evidenced by the acquisition of N-Gain values of $71 \%$ in the experimental class and $48 \%$ in the control class, as well as obtained $t_{\text {count }} 8.807$, which indicates $t_{\text {count }}>t_{\text {table }}$. The increase of students' ability to perform scientific work in the experimental class showed $72 \%$ of students in a very good category and $28 \%$ of students in a good category. Meanwhile, in the control class, only 53\% of students in a very good category and $47 \%$ in a good category. Thus, creative problem-solving learning through the open-ended experiment is effective in increasing students' understanding and scientific work.

\section{ACKNOWLEDGMENT}

Researchers would like to thank their gratitude to the Postgraduate School Science Education Study Program of Pakuan University, which has supported this research.

\section{REFERENCE}

Adel, M.E., \& Yousra S.P. (2020). The Effect of Self-Regulated Learning Strategies on Developing Creative Problem Solving and Academic Self-Efficacy Among Intellectually Superior High School Students. International Journal of PsychoEducational Sciences, 9(1), 97-106.

Ahmad, B., \& Parlindungan, S. (2015). Experiment Based Creative Problem Solving (CPS) Learning Strategies to Improve Cognitive Ability and Creative Thinking Skills. Jurnal Pengajaran MIPA., 20(2), 133-143. 
Aka, E.I., Guven, E \& Aydogdu, M (2010) Effect of Problem Solving Method on Science Process Skills and Academic Achievement. Journal of Turkish Science Education, 7(4), 13-25.

Akinbobola, A.O., \& Afolabi, F. (2010). Analysis of Science Process Skills in West African Senior Secondary School Certificate Physics Practical Examinations in Nigeria. American-Eurasian Journal of Scientific Research, 5(4), 234-240.

Alfi, S., Dawud, D., Heri, S., \& Endah, T.P. (2019). Creative Thinking Patterns In Student's Scientific Works. Eurasian Journal of Educational Research. 19(81): 21-36.

Amna, E. (2017). Laboratory as a Chemical Learning Facility in Enhancing Knowledge and Scientific Work Skills. Lantanida Journal, 5(1), 89-92.

Arif., Maya, I., \& Syahmani. (2018). Implementation of Problem Based Learning Assisted by Online Discussion of Problem Solving Ability and Chemical Learning Outcomes in the Buffer Solution Material. Journal of Chemistry and Education, 1(3), 237-244.

Ayel, S.L., Hasan, M., \& Mursal, M. (2017). Development of Practicum Module Based on Open Ended Approaches to Increase Student Creativity. Jurnal Pendidikan Sains Indonesia, 5(1), 36-43.

Baker, R.S., Clarke, J.M., \& Ocumpaugh, J. (2016). Towards General Models of Effective Science Inquiry in Virtual Performance Assessments. Journal of Computer Assisted Learning, 32(3), 267-280.

Bartholomew, S.R., \& Strimel, G.J. (2018). Factors Influencing Student Success on Open-Ended Design Problems. International Journal of Technology and Design Education, 28(3), 753-770.

Bethany, R.W., \& Heather, J.L. (2016). Open-Ended Versus Guided Laboratory Activities: Impact on Students' Beliefs About Experimental Physics. Physical Review Physics Education Research, 12(2), 1-8.

Cahaya, S.P., Feriansyah, S., \& Ismu, W. (2019). Effect of Application of Creative Problem Solving Learning Model to Improve Creative Thinking Ability in Solving Physics Problems in High School Students. Jurnal Pendidikan Fisika, 7(2), 149-155.

Chansyanah, D., Liliasari., Agus, S., \& Buchari, B. (2018). Using Project-Based Learning to Design, Build, and Test StudentMade Photometer by Measuring the Unknown Concentration of Colored Substances. Journal of Chemical Education, 95(3), 468-475.

Devin, S.I., \& Kimberley A.F. (2011). Incorporating Student-Designed Research Projects in the Chemistry Curriculum. Journal of Chemical Education, 88(8), 10691073.

Diana, H., Mohamad, A., Mimien, I., Sri, I., \& Muhammad, A. (2018). Integration of Project Activity to Enhance the Scientific Process Skill and Self-Efficacy in Zoology of 
Vertebrate Teaching and Learning. EURASIA Journal of Mathematics, Science, and Technology Education, 14(6), 2475-2485.

Diane, J.K., Brian, N., Catherine, S., \& Younsu, K. (2013). Improving Science Assessments by Situating Them in a Virtual Environment. Education Sains. Education Sciences, 3, 172-179.

Farsakoglu, O.F., Sahin, C., Karsli, F., Akpinar, M., \& Ultay, N. (2008). A Study on Awareness Levels of Prospective Science Teachers on Science Process Skills in Science Education. World Applied Sciences Journal, 4(2), 174-182.

Fraenkel, J.R., \& Norman E.W. (2007). How to Design and Evaluate Research in Education. New York: Mc Graw Hill.

Fian, T., Elfi, S., \& Tri, R. (2012). Effectiveness of Creative Problem Learning Models Solving Completed with Learning Media Virtual Laboratory on Learning Achievement Students in Class XI IPA Colloid Materials Even Semester SMA Negeri 1 Karanganyar Study Year 2011/2012. Jurnal Pendidikan Kimia, 1(1), 74-79.

Gail, D.C., Mauro, M., \& David, F.T. (2007). Achieving Greater Feedback and Flexibility Using Online Pre-Laboratory Exercises with Non-Major Chemistry Students. Journal of Chemical Education, 84(5), 884-888.

Hake, R.R. (1998). Interactive Engagement vs Traditional Methods: a Six ThousandStudent Survey of Mechanics Test Data for Introductory Physics Course. American Journal of Physics, 66(1), 64-74.

Hilarius, J.D., Herawati, S., \& Peter, N. (2019). Enhancing Different Ethnicity Science Process Skills: Problem-Based Learning through Practicum and Authentic Assessment. International Journal of Instruction, 12(1), 1207-1222.

Hobri., Irma, K.U., Nanik, Y., \& Dafik, D. (2020). The Effect of Jumping Task Based on Creative Problem Solving on Students' Problem Solving Ability. International Journal of Instruction, 13(1), 387-406.

Jalimah, D., Abdul, H., \& Muhammad, K. (2019). Creative Problem Solving (CPS) Learning Model to Increase Scientific Creativity and Learning Outcomes of Supporting Material. Journal of Chemistry and Education, 3(1), 23-30.

Kate J.G., Nicholas, T.J., Chris P.S., \& Edward J.M. (2014). Implementing a StudentDesigned Green Chemistry Laboratory Project in Organic Chemistry. Journal of Chemical Education, 91(11), 1895-1900.

Kazembe, T., \& Methias S. (2010). Effectiveness of Teachers at Preparing Grade 7 Candidates for Environmental Science Examinations, Eurasian Journal Physical Chemistry Education, 2(2), 64-81.

Kubiatko, M. (2017). Effect of Active Learning on Perception of And Performance in Science Subjects. Journal of Baltic Science Education, 16(4), 444-445. 
Kubiszyn, T. \& Gary, D.B. (2015). Educational Testing and Measurement. United States of America

Laite, L, \& Luis, D. (2013). Laboratory Activities, Science Education, and Problem Solving Skills. Procedia Social and Behavioral Sciences, 106, 1677-1686.

Lambertus, L., Arapu., \& Patih, T. (2013). Application of Open-ended Approach to Improve Mathematical Creative Thinking Ability of Middle School Students. Jurnal Pendidikan Matematika, 4(1), 73-82.

Laura, R., Maria, K., Robert, C., Emily, S., Thomas, G., \& Katie, L. (2019). Detecting Microplastics in Soil and Sediment in an Undergraduate Environmental Chemistry Laboratory Experiment That Promotes Skill Building and Encourages Environmental Awareness. Journal of Chemical Education, 96(2), 323-328.

Lim, K.K., Zaleha, I., \& Yudariah, M.Y. (2016). A Review of Open-Ended Mathematical Problem. Anatolian Journal of Education, 1(1), 1-18.

Margaret, B., Denise, P., \& Ignacio, J., Ferrer, V. (2015). Demystifying the Chemistry Literature: Building Information Literacy in First-Year Chemistry Students through Student-Centered Learning and Experiment Design. Journal of Chemical Education, 92(1), 52-57.

Martunis, M. (2014). Open Ended Learning in the Broad Triangle Area of SMA Negeri 2 Indrajaya Students. Journal Sains Riset, 1(19), 13-21.

Munroe, L. (2015). The Open-Ended Approach Framework. European Journal of Educational Research, 4(3), 97-104.

Nancy, W., Tomohiro, K., Kikelomo N.S., Ariana O.H., Sameer, P., Danielle M.Z., Rachel L.W., Devki B.K., \& Anne J.M. (2019). Student-Designed Green Chemistry Experiment for a Large-Enrollment, Introductory Organic Laboratory Course. Journal of Chemical Education, 96(11), 2420-2425.

National Research Council. (2000). Inquiry and National Science Education Standards: A Guide for Teaching and Learning. New York: National Academic Press.

Nicolas, V., Florencia, L., Kenneth, I., Marıa, N., Rodrıguez, A., \& Julia, T. (2019). Online Pre-Laboratory Tools For First-Year Undergraduate Chemistry Course in Uruguay: Student Preferences and Implications on Student Performance. Journal of Chemistry Education Research and Practice, 20(1), 229 -245.

Noer, S.H. (2011). Mathematical Creative Thinking Ability and Open-ended Problem Based Mathematics Learning. Jurnal Pendidikan Matematika, 5(4), 104-111.

Noorsalim, M., Nurdiniah, S. H., \& Saadi, P. (2014). Implementation of Website Based E-Learning Learning to Improve Learning Outcomes and Motivation of Class XI Science 1 Students on the Material of Solubility and Solubility Results at SMAN 12 Banjarmasin. Jurnal Inovasi Pendidikan Sains, 5(1), 99-105. 
Novikasari, I. (2009). Development of Students' Critical Thinking Abilities through Open Ended Mathematics Learning in Primary Schools. Jurnal Pemikiran Alternatif Kependidikan, 14(2), 346-364

Nurdeli, L.S., Rahmatsyah, R., \& Mariati, P.S. (2017). The Influence of Problem Based Learning Model on Scientific Process Skill and Problem Solving Ability of Student. IOSR Journal of Research \& Method in Education, 7(4), 1-9.

Ottander, C., \& Grelsson, G. (2006). Laboratory work: The Teachers' Perspective. Journal of Biological Education, 40(3), 113-118.

Planinsic, G. (2007). Project Laboratory for First Students. European Journal of Physics, (28), 71- 82.

Raden, H.S., \& Idris, H. (2014). Effect of Open-Ended Approaches and Contextual Approaches Against Students' Problem Solving Capabilities and Attitudes Towards Mathematics. Jurnal Riset Pendidikan Matematika, 1(2), 240-256.

Rahman, A. A., Samingan., \& Khairil, K. (2014). Application of Practicum Based Learning Against Student Learning Outcomes and Scientific Work Ability in the Concept of Circulatory Systems at SMA Negeri 2 Peusangan. Jurnal Edu-Bio Tropika, 2(1), 121-186.

Rebecca, U.E., \& Nsimeneabasi, M.U. (2017). Effects of Practical Activities and Manual on Science Students' Academic Performance on Solubility in Uruan Local Education Authority of Akwa Ibom State. Journal of Education and Practice, 8(3), 202209.

Reynders, G., Erica, S., Renee S.C., \& Rebecca L.S. (2019). Developing Student Process Skills in a General Chemistry Laboratory. Journal of Chemical Education, 96(10), 2109-2119.

Ridong, H., Su, X., \& Chich-Jen, S. (2017). A Study on the Application of Creative Problem Solving Teaching to Statistics Teaching. EURASIA Journal of Mathematics Science and Technology Education, 3(7), 3139-3149.

Risna, R., Abdul, H., \& Atiek, W. (2017). Improving the Generic Science Skill and Learning Outcomes using Creative Problem Solving Models Completed Virtual Laboratory Hydrolysis Material Class XI IPA 2 SMA PGRI 4. Journal of Chemistry and Educations, 1(1), 131-142.

Rosmalinda, D., Rusdi, M., \& Hariyadi, B. (2013). Practical Module Development High School Chemistry Based PBL (Problem Based Learning). Edu-Sains, 2(2), 1-7.

Royston, R. \& Roni, R.P. (2017). Creative Self-Efficacy as Mediator Between Creative Mindsets and Creative Problem-Solving. Journal of Creative Behavior, 53(4), 472-481

Ruomei, G. (2015). Incorporating Students' Self-Designed, Research-Based Analytical Chemistry Projects Into the Instrumentation Curriculum. Journal of Chemical Education, 92(3), 444-449. 
Ryan S.N., Godfrey, T.J., Nicholas T.M., \& Craig C.W. (2016). Undergraduate Student Construction and Interpretation of Graphs in Physics Lab Activities. Physical Review Physics Education Research, 12(1), 1-19.

Safaruddin, S., Nurlaiha, I., Juhaeni, J., Harmilawati, H., \& Laeli, Q. (2020). The Effect of Project-Based Learning Assisted by Electronic Media on Learning Motivation and Science Process Skills. Journal of Innovation in Educational and Cultural Research, 1(1), 22-29.

Satish, G.J., \& Vinayak, N.G. (2019). Attaining Competencies in Programme Outcomes Through Open-Ended Experiments. Africa Education Review, 17(1), 116-140.

Seechalio, T., Natakuatoong, O., \& Wannasuphoprasit, W. (2011). The Instructional Model Based on Engineering Creative Problem Solving Principles to Develop Creative Thinking Skills of Undergraduate Engineering Students. European Journal of Social Science, 26(3), 408- 420.

Siti, N., \& Soeprodjo, S. (2015). The Effectiveness of the Interactive Flash Assisted Creative Problem Solving Learning Model Against Learning Outcomes. Jurnal Inovasi Pendidikan Kimia, 9(1), 1440-1449.

Siti, J.H., \& Sufen, C. (2019). Effects of Guided Inquiry Virtual and Physical Laboratories on Conceptual Understanding, Inquiry Performance, Scientific Inquiry Self-Efficacy, and Enjoyment. Physical Review Physics Education Research, 15(1), 116.

Soka, H., Heru, K., Dadan, R., \& Adi, P. (2019). The Effect of Laboratory Work Style and Reasoning with Arduino to Improve Scientific Attitude. International Journal of Instruction, 12(2), 321-336.

Sudjana, N. (2002). Research on the Results of the Teaching and Learning Process. Bandung: Remaja Rosdakarya.

Tatyana, N.B., Elvir, M.A., Angelina, O.Z., Arkady, V.M., Margarita, E.B., Irina, A.S., \& Olga, S.A. (2020). The Analysis of Using Active Learning Technology in Institutions of Secondary Vocational Education. International Journal of Instruction, 13(3), 371386.

Tina, O., Nicholas, P., \& Christopher, L. (2013). A Study of Approaches to Solving Open-Ended Problems in Chemistry. Chemistry Education Research and Practice, 14(4), 468-475.

Turner, J. \& Parisi, A. (2008). A Take-Home Physics Experiment Kit for On-Campus and Off-Campus Students, 54(2), 20-24.

Vidal, R.V.V. (2010). Creative Problem Solving an Applied University Course. Journal of Informatics and Mathematical Modelling Technical, 30(2), 405-426. 
Wardani, S. (2008). Development of Science Process Skills in Learning Thin Layer Chromatography Through Micro Scale Practicums. Jurnal Inovasi Pendidikan Kimia, 2(2), 317-322.

Wawan, K., Darmaji, D., Astalini, A., Dwi, A.K., Hidayat, M., Nugroho, K., \& Linda, Z.N. (2019). Multimedia Physics Practicum Reflective Material Based on Problem Solving for Science Process Skills. International Journal of Evaluation and Research in Education, 8(4), 590-595.

Widyatmoko, A. \& Pamelasari, S.D. (2012). Project Based Learning to Develop Natural Science Teaching Aids by Using Used Materials. Jurnal Pendidikan IPA Indonesia, 1(1), 51-56.

Wulandari, N. \& Mashuri, W. (2014). The Effectiveness of CIRC Learning with Open Ended Approach to Creative Thinking Ability of Class VIII Students Cube-block material. Unnes Journal of Mathematics Education, 3(3), 231-240.

Yunnel, D.P., \& Yarman, Y. (2019). Application of Creative Problem Solving Learning Model to Improve Understanding of Mathematical Concepts of Class VII Students of SMP Negeri 20 Padang. Jurnal Edukasi dan Penelitian Matematika, 8(3), 146-152.

Zainuddin., Suyidno., Dewi, D., Saiyidah,, M., Mohamad, N., Leny, Y., \& Titin, S. (2020). The Correlation of Scientific Knowledge-Science Process Skills and Scientific Creativity in Creative Responsibility Based Learning. International Journal of Instruction, 13(3), 307-316. 